\title{
Enhancing the First-Year Experience for Business Students: Student Retention and Academic Success
}

\author{
Pamela L. Cox \\ Elizabeth Dunne Schmitt \\ Paula E. Bobrowski \\ Glenn Graham \\ State University of New York at Oswego
}

\begin{abstract}
This study examined the academic success and retention of first-year business students enrolled in a course designed to develop skills for academic success, provide a sense of community, ease the transition from high school to college, and provide a realistic preview of business school expectations. The course was designed to create the conditions regarded in the retention literature as critical in promoting academic success and persistence among first year students. Participating students were found to have lower academic disqualification rates, earn higher grade point averages, and continued their enrollment to the fall term of their second year at a higher rate.
\end{abstract}

\section{Introduction}

The first year of university study is in many ways the most formative and often the least satisfactory in terms of concept, curriculum, and pedagogy. As a result, freshman-the students who need the very best teaching - may actually receive the worst, and more of them fall away by the end of the freshman year than at any other time (Boyer, 1997; The Boyer Commission Report, 1995). In fact, the first year is the most crucial period in student retention with more than half the students who drop out of college doing so in their first year (Consortium for Student Retention Data Exchange, 1999; Levitz, Noel, \& Richter, 1999; Tinto, 1999). Colleges with high first-year retention rates have been found to also have a higher percentage of students graduating within four years (Lau, 2003).

As a result, many institutions are becoming increasingly concerned with improving retention rates, academic achievement, and student satisfaction during the first year (Barefoot, 1994; Kluepfel \& Roberts, 1994; Murtaugh, Burns, \& Schuster, 1999; Sanders \& Burton, 1996; Starke, Harth, \& Sirianni, 2001; Tinto, 1987). By re-examining the first-year experience and implementing new and innovative learning strategies, universities can help make students' transition into college easier and improve student retention rates (Barefoot, 1993; Cuseo, 1991; Davis, 1992; Federman Stein, 1997; Fidler, 1991; Logan, Salisbury-Glennon, \& Spence, 2000; Schutte \& Malouff, 2002; Soldner, Lee, \& Duby, 1999; Starke, Harth, \& Sirianni, 2001; Tinto, 1993). Data indicate that more than $70 \%$ of colleges and universities now offer some type of first-year program (National Resource Center for the First-Year Experience and Students in Transition, 2000; Skipper, 2002). 
At the same time, there has been a call for radical reform in business education (Accounting Education Change Commission, 1990; Porter \& McKibbin, 1988). Critics of business education point out that new skills are required for managing diversity, globalization, downsizing and restructuring; skills that are lacking in today's graduates (Mason, 1992). Business schools have also been criticized for omitting training in skills necessary to developing the ability to function as a generalist rather than a specialist in business (Chanko \& Roberts, 1996). In addition, students entering business school may not have a clear idea of what a career in business is about. First-year business courses that use a hands-on, experiential approach can help students with little or no organizational experience to develop a better understanding of the connections between themselves and business (Lamb, Lee, \& Vinton, 1997). There is little question that there is a call to reconfigure the first-year experience to bring together the teaching of discipline based concepts in harmony with developing students' specific business skills in order to prepare them to meet the challenges of today's managers.

MGT 110 was developed in response to calls for reform in the first-year curriculum and business education. The course is designed to help students acquire the skills necessary to succeed in business school, while at the same time easing the transition from high school to college and building the first-year student's sense of community with the university and the business school. This paper provides a review of the literature on student retention and first-year courses designed to increase retention; a description of the MGT 110 course design, implementation, and method of instruction; and an assessment of the course's effect on student success and retention. A future research agenda is outlined with the focus on identifying factors leading to increased academic persistence.

\section{Review of the Literature}

Several factors seem to be related to lower retention rates at the college level. Public universities, particularly those with "open" admission standards, have higher attrition rates than do private universities (ACT, 2000; Tinto, 2002). More selective admissions standards have been related to higher retention rates (ACT, 2000). Studies show that the following factors put students more at risk: lower SAT score, lower high school average, unmet financial need, and lower household income (Reason, 2003; Tinto, 2002). Hoyt \& Winn's (2004) review of the literature identified financial concerns as the most frequent reason for failing to return to college; thus, students with unmet financial need are at highest risk for attrition. Male students are less likely to persist than female students; colleges with a lower percentage of female students are likely to have higher attrition rates (Tinto, 2002). Health and psychosocial variables such as smoking, drinking, health-related issues, and maladaptive coping strategies have all been linked to decreased retention (DeBarard, Spielmans, \& Julka, 2004).

University grades have been found by several studies to be the best predictor that students will persist with college (Allen, 1999; Murtaugh, Burns, \& Schuster, 1999). First year cumulative GPA is a particularly important factor in determining retention between the first and second year (Allen, 1999; Mitchel, Goldman, \& Smith, 1999; Murtaugh et 
al., 1999; Reason, 2003). States Reason (2003, p. 185) in a recent review of the retention literature: "... when considering retention between the first and second year of college, student achievement in college, as measured by first-semester grade point average, proves to be a significant variable in retention." In fact, first-year GPA may have the greatest impact on student retention (Allen, 1999), accounting in one study for $56 \%$ of the variance, an improvement in prediction over high-school GPA and SAT scores alone (25\%) (DeBerard, Spielmans, \& Julka, 2004).

Student academic integration (interest and focus on learning) and social integration (sense of social belonging and development of friendships) have been associated with retention as has goal commitment to graduating with a certain degree (Tinto, 1979; 1982). In fact, there seem to be reciprocally interactive causal relationships among these three factors (integration, academic performance, and goal commitment) creating the possibilities of self-perpetuating upward or downward cycles beginning in the freshman year (Napoli \& Wortman, 1999; Thomas, 2000). In other words, it is important to "get students started right", preferably in the first semester.

An extensive body of literature identifies the following conditions as critical in promoting academic success and retention among first year students: information and advice, support, involvement, and learning (Tinto, 1999). Studies of student retention identify several key factors in decreasing student attrition rates and enhancing student transition from high school to college:

1. Early and frequent interaction with faculty, staff, and peers

2. Clearly communicated academic expectations and requirements

3. Learning opportunities that increase involvement with other students

4. Academic, social, and personal support

\section{Interaction with Faculty, Staff, and Peers}

A number of studies identify early and frequent interaction with faculty, staff, and peers both in and out of the classroom as a key factor in promoting student academic integration and persistence with college (Astin, 1975; Gordon \& Grites, 1984; Johnson, 1998; Kuh, Schuh, \& Whitt, 1991; Milem \& Berger, 1996; Seidman, 1991; Thomas, 1990; Tinto, 1990, 1993, 1999, 2002; Wagener \& Nettle, 1998). States Tinto (1999): “ ... involvement matters, and at no point does it matter more than during the first year of college when student attachments are so tenuous and the pull of the institution still so weak" (p. 6). Deliberate attention from faculty and staff has been shown to help students develop feelings of academic competence and a sense of identity (Sidle \& McReynolds, 1999).

Enrolling students in specially designed freshman courses ("first-year experience courses") appears to be one strategy that is quite effective in promoting interaction and involvement with faculty, staff, and peers. These courses typically have the following characteristics (Soldner, Lee, \& Duby, 1999): 
1. Provide students with academic support and direction

2. Assist students to become users of campus and community resources

3. Encourage students to engage in career and college major exploration activities

4. Afford students opportunities to develop personally and to connect socially with others

Participation in a freshman course was predictive of better persistence even if the influence of possibly confounding variables (i.e. - age, high school GPA, SAT scores, residency) was factored out (Murtaugh, Burns, \& Schuster, 1999). Studies confirm that students enrolling in specially designed first-term "experience" courses tend to complete more credit hours, earn higher cumulative grade point averages, and return to the institutions at higher rates than students who did not enroll in such first-term courses (Cuseo, 1991; Davis, 1992; Fidler, 1986; Hyers \& Joslin, 1996; Richardson, 1994; Strumpf \& Hunt, 1993). These results occurred even though the students who did not enroll in first-year "experience" courses were often described as being more academically qualified, on the basis of standardized test scores and high school ranks, than were students who enrolled in the courses (Sidle \& McReynolds, 1999).

"Block" scheduling is another strategy aimed at increasing student interaction with faculty and peers (Soldner, Lee, \& Duby, 1999). Block scheduling builds freshman learning communities by allowing first-time freshmen to pre-enroll with other interested students in a block of 3-4 courses, one of which is often a "first-year experience" course. Benefits of block scheduling include increased student and faculty interaction that focuses on academic content (Soldner, Lee, \& Duby, 1999), greater student satisfaction, and lower attrition rates (Baker \& Pomerantz, 2000).

\section{Clearly Communicated Academic Expectations and Requirements}

Clearly communicated academic expectations have been associated with higher academic performance and, ultimately, greater persistence (Chickering, 1969; Congos, 2002; Sidle \& McReynolds, 1999; Tinto, 2002). Communicating academic expectations and requirements involves clearly articulating the level of work expected and the level of challenge (Tinto, 2002). It appears to be especially important that colleges communicate "high" academic expectations (Chickering, 1969; Tinto, 2002) for as Tinto states (p. 6): "No student rises to low expectations." Along with communicating high academic standards, student performance is enhanced with frequent feedback and expressed confidence in students' ability to meet high standards. Self-efficacy for educational requirements has been associated with higher GPA and persistence (Lent, Brown, \& Larkin, 1991).

\section{Learning Opportunities that Increase Involvement with Other Students}

The learning and performance of first-year students is enhanced with increased involvement with other students (Congos, 2002; Sidle \& McReynolds, 1999; Tinto, 1997, 1999, 2002). One way to increase involvement with other students is through collaborative or shared learning groups that allow students to develop social and 
academic networks (Tinto, 1997, 2002). These networks provide critical support, enabling students to persist in their attainment of degree requirements (Tinto, 2002). Collaborative learning has also been found to produce higher achievement, healthier psychological adjustment, and improved analytical, communication, and interpersonal skills (Johnson, Johnson, \& Smith, 1991), and increased opportunities for class discussion (Braxton, Milem, \& Sullivan, 2000). Block scheduling is yet another way to increase exposure of first-year students to their peers. Student enrollment in at least one course where class size is kept small also increases student involvement and interaction (Murtaugh, Burns, \& Schuster, 1999).

\section{Academic, Social, and Personal Support}

In order to smoothly transition into college, students need to be provided with tools and support for managing both the academic and social aspects of school (Frost, 1993; Noel, Levitz, \& Salur, 1985; Pascarella \& Terenzini, 1991; Tinto, 1987). Increased involvement with peers and faculty provides student with the academic, social, and personal support critical to academic persistence (Tinto, 1997, 2002). Another effective way of providing academic and social support is to assign upper level students to work with first-year students as mentors and role models (Miller, 1991; Robert \& Thomson, 1994; Wagener \& Nettles, 1998). One study found that first-year students mentored by upper-level students had significantly higher final grades than did students in a control group (Rodger \& Tremblay, 2003).

Making it easier for students to connect with campus resources is an additional way to provide academic support (Soldner, Lee, \& Duby, 1999). For instance, instructors might accompany students to technology training sessions, assist librarians in teaching students how to use a college library, and provide hands-on training in time management skills. It may be especially important that first year courses emphasize academic support and skill development. First year programs that emphasize academic support may have the greatest impact on retention. One study compared students enrolled in a first year seminar that emphasized the development of learning skills and academic success strategies (strategy-focused seminar) with students enrolled in a first year seminar that emphasized socialization and social support (socialization-focused seminar). First year students enrolled in the strategy-focused seminar were significantly more likely to re-enroll the following fall than were first year students enrolled in the socialization-focused seminar (Ryan \& Glenn, 2004, p. 19). State Ryan \& Glenn (p. 20): "In our study, the strategy-based seminar appears to immunize first-time freshmen against the damaging effects of first-semester performance on one-year retention rates. We believe it does so by developing their learning skills and their sense of academic efficacy to an extent that enhances academic integration and institutional commitment."

\section{Course Overview}

The primary focus of MGT 110 is on the development of learning skills and academic success strategies because we believe (and the literature supports this belief) that this emphasis results in higher first semester GPAs and greater persistence from the first to the second year of college. The course also attempts to provide students with a social 
support structure through block scheduling, peer and faculty mentoring, and an emphasis on teamwork and collaborative learning.

\section{$\underline{\text { Course Objectives }}$}

MGT 110 utilizes a combination of delivery methods. Students attend lectures and are assigned readings as part of the traditional approach to learning. Concurrently, students participate in interactive/experiential learning activities where they can learn and apply important key concepts in several key areas including knowledge building, critical thinking, and decision-making while developing the skills that are necessary to be effective both academically and professionally.

The MGT 110 curriculum is designed to meet the following objectives:

- Develop skills necessary for academic success

- Ease students' transition from high school to college

- Provide first-year students with a sense of community

- Improve academic performance and retention rates

- Provide a realistic preview of the School of Business and the business curriculum

Implementation/Method of Instruction

MGT 110 is a required course for all business students and fulfills their general education critical thinking, and lower-division, discipline-related writing requirements. The course includes one fifty-five minute lecture and two fifty-five minute recitation meetings per week. The lectures are attended by 150-200 freshmen that have declared their majors to be in the field of business. A business faculty member, or another appropriate professional familiar with the designated topic, presents the main lecture, panel, or discussion topic during the weekly lecture. The following topics are introduced during the weekly lecture sessions and supplemented with experiential material during the recitation sessions: group processes, critical thinking and problem solving, research skills, stress and time management skills, contemporary business issues, and business communications skills.

The recitation sessions meet twice a week and are attended by $15-19$ students per section. Each recitation section is facilitated by a section instructor (business faculty member) who is responsible for teaching and implementing assignments and experiential activities in the areas of critical thinking, writing, and team-work as they relate to the business context.

Instructors are assisted in each section by two undergraduate teaching assistants. The teaching assistants grade some of the homework assignments, take attendance, and act as mentors to the students. Teaching assistants play a crucial role in the delivery of the course in that they relieve much of the logistical burden of the course and help firstyear students in their transition from high school to college. 
The delivery of the course is overseen by a course coordinator (a business faculty member) who coordinates the activities of the recitation instructors and teaching assistants, plans the content of the lecture sections, and schedules guest lecturers. The course coordinator also meets with the recitation instructors and teaching assistants on a weekly basis to share ideas, answer questions, and discuss concerns relating to the delivery of the course. Figure 1 (below) depicts the topics, assignments, and exercises used to meet the course's objectives.

Figure One - MGT 110 Topics and Assignments

\begin{tabular}{|c|c|}
\hline Teamwork & Computer Skills \\
\hline $\begin{array}{l}\text { - Team Charter assignment } \\
\text { - Leadership Weekend Training } \\
\text { - Industry report/presentation }\end{array}$ & $\begin{array}{l}\text { - MSWord, PowerPoint, Excel } \\
\text { - Email } \\
\text { - Internet/library databases }\end{array}$ \\
\hline Critical Thinking & Business Writing \\
\hline $\begin{array}{l}\text { - } \text { Evaluating evidence and } \\
\text { arguments } \\
\text { - Recognizing errors in thinking } \\
\text { - Group decision-making } \\
\text { - } \text { Persuasion and application } \\
\end{array}$ & $\begin{array}{l}\text { - Journal writing } \\
\text { - Abstract writing } \\
\text { - Industry report } \\
\text { - Resume/Portfolio development }\end{array}$ \\
\hline Research & Oral Communication Skills \\
\hline $\begin{array}{l}\text { - Library overview } \\
\text { - Industry report } \\
\text { - Critical thinking assignments } \\
\text { - APA documentation }\end{array}$ & $\begin{array}{l}\text { - } \text { Classroom discussion } \\
\text { - Presentation development/delivery } \\
\text { - Experiential exercises } \\
\text { - Industry presentation }\end{array}$ \\
\hline Contemporary Business Issues & $\begin{array}{l}\text { Managing the Academic Experience } \\
\text { Building a Sense of Community }\end{array}$ \\
\hline $\begin{array}{l}\text { - } \text { Leadership } \\
\text { - Group Processes } \\
\text { - } \text { Civersity and Globalization } \\
\text { - Business Ethics }\end{array}$ & $\begin{array}{l}\text { - Stress/Time management } \\
\text { - Registration and advisement } \\
\text { - Peer mentoring } \\
\text { - Leadership training }\end{array}$ \\
\hline
\end{tabular}

Improving Academic Success of First-Year Business Students

An extensive body of literature identifies the following conditions as critical in promoting academic success and retention among first year students: information and advice, support, involvement, and learning (Tinto, 1999). Students are more likely to be successful and persist in their education when they are provided with clear information 
about academic requirements, receive academic, social, and personal support, and are involved in learning experiences with other first-year students.

\section{Information and Advice about Requirements and Expectations}

MGT 110 is designed to provide students with a clear understanding of the requirements and expectations of the business school. One week of the course is dedicated to providing students with information about school requirements, registration, and advisement. The session is followed by mandatory meetings with the students' faculty advisors. An additional week is dedicated to introducing students to the requirements and career opportunities corresponding to the available business majors: marketing, business administration, management science, human resource management, accounting, and finance. Expectations of the business school are emphasized in the teaching of the following skills: writing, presentation, research, and teamwork. Students are expected to submit completed, proofread assignments on time. Class attendance is required and professional behavior is emphasized in the classroom.

\section{Academic, Personal, and Social Support}

The first semester of college can be a stressful one as students are often faced with challenges not encountered in high school. In order to better manage the stressors of college, one of the lecture sections is devoted to stress management techniques. A time management assignment is assigned to provide students with a better understanding of how they currently spend their time and how they might use time management techniques to manage their time more effectively. Academic support is provided in the recitation through close contact with the instructors and teaching assistants, and by introducing students to campus services like the writing center and office of learning services. The course emphasizes development of the skills necessary to obtain academic success in the School of Business with sessions on writing, research, computer, critical thinking, and presentation skills development. Reading assignments in the required text (Bobrowski \& Cox, 2004) include information on effective lecture notetaking, reading comprehension and test-taking strategies, time management, and information literacy and study skills. Students are also provided with technology training sessions, introduced to the college library, and attend sessions on obtaining internships, international education opportunities, and career exploration.

First year students receive study tips and academic skill training from the teaching assistants as well as the faculty. The teaching assistant's role is not limited to academic support; we have found that students develop close relationships with the teaching assistants and seek their help with a variety of nonacademic issues related to making a smooth transition to college.

\section{Involvement in Learning Experiences with Other Students, Faculty, and Staff}

In most business schools, students do not take business courses until their sophomore or junior year. One objective of MGT 110 is to develop a sense of community among first-year business students through exposure to first-year and upper-level business 
students, business faculty, and School of Business alumni in the first semester. All firstyear business students meet together once a week in the lecture section of the course where they are introduced to upper-level business students, business faculty and alumni in a series of presentations, panel discussions, and interactive discussion. During the bi-weekly recitation meetings, students are provided with a more intimate setting for getting to know business faculty, upper-level teaching assistants, and other first-year business students. Student representatives are invited to come into the recitation sessions to provide students with information about becoming involved in the various student organizations on campus. The recitation sessions are designed to encourage interaction and discussion, and to provide academic support. Involvement with other business students is further encouraged through block scheduling. Students are block scheduled so that they are exposed to other first-year business students not only in MGT 110 but also in their other first-semester required courses.

MGT 110 has been structured so that shared learning and active participation is the norm. Participation is even encouraged in the lecture sessions-students develop questions to ask the presenters before hand and receive participation points for asking and answering questions during the lecture. Each student is required to have a plastic name-plate on their desk so that lecture presenters can call on students by name. We further encourage participation by encouraging presenters to move up and down the aisles of the lecture hall answering questions and calling on students in all areas of the room.

Shared learning is encouraged by organizing students in teams at the beginning of the semester. Each team drafts its own charter as a formal agreement among members documenting responsibilities and expectations (Cox \& Bobrowski, 2000). An industry report is assigned as a team project in order to develop student collaborative skills and expose students to the collaborative nature of business. Team efforts culminate in a single research report that embodies the blended work of all the members. A three-hour intensive team training session provides students with tools for enhancing the effectiveness of their teams and improving interpersonal relationships. It is also an "outof-class" bonding experience intended to help students become more comfortable with one another, build communication with team members, and further develop a sense of community among business students.

\section{Assessing the Impact of MGT 110 on Student Outcomes}

The effectiveness of first-year programs can be evaluated using several different methods including anecdotal information, descriptive statistics and inferential statistics (Congos \& Schoeps, 1999). In our opinion, the use of inferential statistics is an essential piece to the accurate and detailed assessment of the effectiveness of these programs. To this end we use single-equation probit models to estimate the probability of retaining first year students using a database of the fall 2001 freshman class. This database contains academic, demographic, and financial variables for over 1300 students, along with information about their participation in various first-year programs. The data are used to estimate the probability of retention, academic disqualification, and 
first-year GPA. Our results indicate that MGT 110 is effective in increasing retention and decreasing the probability of academic disqualification. We also find the course to have a positive impact on first-year GPA.

\section{The Data}

The data for this study are from the 2001 freshman class, admitted to the school for the Fall 2001 semester. The database includes over 1300 students, with 1136 students admitted under general admissions standards. We select variables in several categories for use in estimating the probability that students return, the probability of academic disqualification, and GPA. A complete list of variables is summarized in Appendix A.

Demographic variables include various data on sex, age, race, living arrangements, and home state. Students self-report their race choosing White, Hispanic, Asian or Pacific Islander, Black (non-Hispanic), American Indian/Native Alaskan or Other. The variable MINORITY is one where race is reported as Black, Hispanic, or Native American, traditionally a high-risk population for attrition. Age is calculated based on the reported date of birth and September 1, 2001. For each student the residence hall or OFF is reported for local living arrangements. OFF is one if the student lives off campus. Also included in this category is the variable UNDEC, which is one if the student is admitted without declaring a major.

Academic variables include SAT scores, high school average, and GPA for the 20012002 academic year. SAT is the highest combined SAT score for each student. For all freshmen, 4 percent of SAT scores are missing. Students admitted under special programs and students beginning school over five years after leaving high school are not required to submit SAT scores. For this reason, SAT scores are not used as an explanatory variable in this study. HSAV is the student's high school average. Only 25 high school averages are missing from the data set. Those observations are excluded from this analysis.

Financial variables include financial information in the form of types of financial aid awarded, and unmet financial need. LOAN, WKST, and GRANT equal one if the student is receiving that type of aid. NEED is unmet need, a dollar calculation made at the campus level that indicates the amount of tuition, fees, and room and board not covered by financial aid or expected student/parent contribution. Although household income is reported to the federal government for those receiving aid, household income is missing for 13 percent of our observations, while unmet need is reported for all students, so we use unmet need to measure the student's financial situation. MGT110 takes the value of one if the student is enrolled in the respective course. Finally, there are two binary variables to measure student outcomes. The first, RET, measures retention. RET is one if the student was registered at the college for the fall 2002 semester; i.e. returned for a second year. DQ measures academic disqualification. DQ is one if the student finished the first year with a cumulative GPA of less than 1.76. Students earning a GPA of less than 1.76 in their first year may return for the fall 2002, 
if they successfully appeal disqualification. However, DQ is intended to measure only the potential for disqualification, regardless of whether a student successfully appeals and is readmitted for fall 2002.

There are several variables not available to us that could be important for retention. Hours worked at a job on or off campus could affect academic success and feelings of belonging or attachment to the institution. Unfortunately, this database does not allow us to investigate this hypothesis. Student leadership and involvement in extra-curricular groups and related alumni are also potentially important, but unavailable in this database.

Appendix B provides a breakdown of academic, demographic, financial and retention variables across the general student population and those enrolled in MGT 110. Looking at the overall retention rate, MGT 110 students return at a rate that is not statistically different from the overall college retention rate of 78 percent. However, as a group, the MGT 110 students have lower SAT scores and high school averages, a higher percentage of minority students and a higher percentage of males, all of which have been associated with lower retention numbers. A probit estimation, controlling for the academic and demographic differences, is the better way to assess the impact of MGT 110 on retention and academic success.

\section{Estimation Results}

Using a single equation probit model, we estimate the probability that a Fall 2001 freshman returns in the Fall 2002. We also estimate separately the probability that a student earns a GPA below 1.76, the cut-off for academic disqualification. Specifically we estimate the coefficients for the following two equations:

$$
\begin{aligned}
& \operatorname{Prob}(\mathrm{RET}=1)=\Phi\left(\beta^{\prime} \mathrm{X}\right) \\
& \operatorname{Prob}(\mathrm{DQ}=1)=\Phi\left(\gamma^{\prime} \mathrm{X}\right)
\end{aligned}
$$

where $\Phi($.$) is the standard normal distribution, \beta$ and $y$ are coefficient vectors, and $X$ is a matrix of the academic, demographic, financial, and first-year program variables described in the previous section. Appendix $C$ reports the estimation results for both retention and disqualification probabilities. Both columns report the marginal probabilities for each variable, i.e. the impact of a one-unit change in that variable on the probability of retention or academic disqualification.

Not surprisingly, high school average (HSAV) has a statistically significant and positive impact on student outcomes, as students with higher averages are more likely to return for a second year and are less likely to disqualify. Receiving work-study financial aid also has a positive impact on student outcomes. Also unsurprising is the negative impact of unmet financial need (NEED) on retention and academic outcomes. While the impact of NEED is statistically significant (i.e. nonzero), it is not practically significant, as 
large changes in unmet need only have a small impact on retention and disqualification probabilities.

Among the demographic variables, being either a male or minority student increased the probability of disqualifying. Living off campus (OFF) also had a negative impact on student outcomes.

Turning our attention to the program of interest, MGT 110, we find that enrollment in this course during the first semester of college does in fact increase the probability of returning for the following academic year, and decreases the probability of academic distress. That is, controlling for the academic and demographic profile of student in MGT 110, we find that the course has a positive impact on student outcomes.

\section{GPA Regression Results}

One problem with single probit equation analysis in this application is that the decision to enroll in the first year programs is not random, and may very well depend on the same factors that affect the probability of returning for the 2002-2003 academic year. There is the potential for selectivity bias: Students who are more likely to return for a second year may self-select into certain programs. While all first-year business students are required to enroll in MGT 110, there are also sample selection issues in the decision to choose a major in the School of Business. In any case, endogeneity and/or selectivity bias will lead to biased parameter estimates and misleading conclusions about the efficacy of first-year programs.

To deal with this issue, we estimate the impact of MGT 110 and the other database variables on student GPA for the academic year. The use of a non-discrete dependent variable (GPA) allows us to use a two-stage estimation process to control for the potential biases described above: First, we estimate the probability that students select certain first year programs. Then we use those estimation probabilities in an OLS regression with GPA as the dependent variable. The regression results are presented in Appendix D. MGT 110 is still associated with superior student outcomes, in this case a higher cumulative GPA for the first year.

\section{What does this mean?}

We offer a couple of examples to illustrate the impact of MGT 110. These are described in Appendices $E$ and $F$. Using the coefficient estimates from our probit and regression equations, we compute probability estimates for retention and disqualification for two hypothetical students with and without MGT 110. In the first example (Appendix E), we consider a white male, age 19, with a high school average of $80 \%$, no financial aid or unmet need, living off campus, and not participating in any first year programs: 
- The probability of such a student returning in the Fall 2002 is $60 \%$.

- The probability of disqualifying after the first year is $49 \%$.

- The predicted first-year GPA is 2.19.

If we enroll that same student in MGT 110 in the Fall 2001:

- Retention probability climbs to $67 \%$.

- Disqualification probability falls to $41 \%$.

- Predicted first-year GPA rises to 2.32 .

In the second example (Appendix F), we consider a minority female, age 18.5, with a high school average of $87 \%$, receiving student loans, and having an unmet financial need of \$1000:

- The probability of such a student returning in the Fall 2002 is $78 \%$.

- The probability of disqualifying after the first year is $11 \%$.

- The predicted first-year GPA of 3.11.

If we enroll that same student in MGT 110 in the Fall 2001:

- Retention probability climbs to $84 \%$.

- Disqualification probability falls to $7.5 \%$.

- Predicted first-year GPA rises to 3.24.

\section{Why does MGT 110 work?}

MGT 110 provides first-year students with academic and social support, increased involvement with peers, faculty, and staff, collaborative learning, and clearly communicated academic requirements and expectations. Students are blocked scheduled into MGT 110 along with two other courses (micro-economics and composition writing); thus increasing exposure and involvement with other first-year students. Class size is kept small in the MGT 110 recitation sections (15-19 students). All of these factors are cited in the literature as critical to academic persistence in the first-year. In addition, an emphasis on developing critical academic strategies and skills may (as suggested by Ryan \& Glenn, 2004) increase student academic self-efficacy, thereby enhancing academic success and institutional commitment. State Ryan \& Glenn (p. 22): "For many, developing the strategies they need to respond effectively to ordinary classroom challenges (e.g., text comprehension, lecture comprehension, test preparation, test taking, and time management) may confer the sense of academic efficacy that promotes a sense of legitimate membership in the academic community and the resolve to remain in that community."

Appendices $\mathrm{G}$ and $\mathrm{F}$ provide additional anecdotal information that suggests reasons why enrollment in MGT 110 results in improved retention, decreased disqualification rates, and increased GPA. Students were asked to complete the EBI First Year Initiative Student Assessment at the end of the semester (Fall 2001). EBI (Educational Benchmarking, Inc.) provides assessment of various college programs and is in 
partnership with several accrediting bodies including AACSB. The First Year Initiative Study was done in partnership with the Policy Center on the First Year of College. The project was designed to provide comparative student feedback for colleges and universities that offer courses or seminars specifically directed toward new incoming students. Appendix G provides mean scores for MGT 110 students on select items from the assessment. Students used the following scale for each item: 1=not at all, 4=somewhat, 7=significantly. Students indicated that taking MGT 110 improved their commitment to completing their degree (mean=5.29). The majority of students planned to return to school for their sophomore year (mean=5.77) and would recommend the university to a friend (mean=5.49). Students felt that MGT 110 improved the degree to which they set priorities (mean=5.23) and completed homework on time (mean=5.68). These factors may have contributed to improved GPA and lower disqualification rates.

The students also seemed to feel that the course increased their involvement with other students. Assessment items that suggest increased involvement include the following:

1. Taking this class improved my ability to meet new people (mean=5.30)

2. The course encouraged students to work together (mean=5.95)

3. Students taking the course felt accepted by other students (mean=5.74) and felt it was easy for them to make friends (mean=5.48)

Our own end of the semester assessment provides additional anecdotal information that may provide insight into the success of students taking MGT 110 (Appendix H). $80 \%$ of students taking the course felt that it clarified School of Business expectations. The majority of students also felt the course introduced them to helpful resources (84\%), improved their ability to manage time (63\%) and stress levels (65\%). $80 \%$ of the students felt the course provided support in their transition to college and $72 \%$ indicated that the course helped them to develop a close bond with other business students.

\section{Conclusion}

The following factors have been identified in the literature as increasing student persistence at college: providing information and advice about academic expectations and requirements, providing academic, personal, and social support, and involving students in learning experiences that increase their exposure to peers, faculty, and staff. Results from the EBI and end of semester assessments indicate that MGT 110 provides these factors to first-year business students. MGT 110 students are more at risk for lower retention rates, lower GPA, and higher disqualification rates. In comparison to the rest of the university population (see Appendix B), students enrolled in MGT 110 have lower SAT scores and high school averages. They are also more apt to be male and minority students, have greater unmet financial need, and lower household income. All of these factors have been found to decrease retention rates. Yet, students enrolled in MGT 110 have an increased retention rate, higher GPAs, and lower disqualification rates when compared to first-year students at our university not enrolled in the course. The finding that MGT 110 students have significantly higher GPAs is especially 
encouraging $(p<.031)$. University grades, particularly first year cumulative GPA, have been found by several studies to be the single most important factor in determining retention and academic persistence (Allen, 1999; DeBerard et al., 2004; Mitchel et al., 1999; Murtaugh et al., 1999; Reason, 2003).

Ryan \& Glenn's (2004) comparison of academic-strategy-based and socialization-based first year seminars suggests it is the emphasis on academic support that matters most. Anecdotal information from our own end of the semester survey and the EBI assessment indicates that students felt MGT 110 increased their commitment to completing homework on time and setting priorities. Students felt the course clarified academic expectations, helped them to develop time and stress management skills, and introduced them to helpful academic resources. These aspects of the course may have helped students to achieve higher first semester GPAs and ultimately resulted in a higher retention rate.

On the other hand, survey results also indicate that students felt the course helped them to meet new people and achieve a closer bond with other students-socialization aspects of the course found in the literature to be related to retention. The challenge remains to pinpoint what aspects of the course contribute most significantly to retention. While it can be difficult to isolate the impact of different variables on retention, further research is needed to identify specific factors leading to increased persistence. Based on anecdotal evidence (student survey results) and student comments, it is our feeling that the academic support and skill development aspects of the course contribute most significantly to higher GPA and student persistence at college. Students have commented that they find MGT 110 to be their most rigorous first semester course, but that it forces them to manage their time with assignments due every week and a challenging team project involving a great deal of research, writing, and coordination among team members. Students have also commented that the academic skills they developed in MGT 110 enabled them to be successful in business courses taken in subsequent years. Thus, taking the course may increase academic self-efficacy among first-year business students. However, further research is needed to support this hypothesis.

A problem in analyzing a dataset such as ours is the importance of missing variables: academic motivation, coping skills, family support structures, and parents' education all play an important role in the success of first year students, yet such information is rarely available in the typical student data collected by admissions and the registrar. Furthermore, if the selection of major or first year program is correlated with these factors, a selectivity bias enters into the analysis of these programs.

One solution to these problems is a richer dataset soon to be available to us from surveys given to freshmen in subsequent years. This data from the Noel-Levitz Retention Management System include highest level of education for each parent, academic rigor of high school, measures of motivation, attitudes towards education, coping skills, and general impressions of the institution. We plan to connect this RMS data to the demographic, academic, and financial data currently available to control for selectivity biases and better identify the specific features of MGT 110. We will also 
attempt to isolate the impact of academic strategy and skill building aspects of the course from socialization aspects. By assembling a longitudinal data set, we can study long-term outcomes such as gradation rates, GPA, and median time to graduation.

Over $70 \%$ of colleges and universities now offer some type of first year program, yet few have attempted any type of assessment beyond the collection of anecdotal data. While limited in its scope, this study does attempt to assess the impact of a first year business course on GPA, retention, and academic disqualification rates. While we have not as of yet been able to isolate the aspects of the MGT 110 curriculum that contribute the most to first year persistence, this study is an important first step in assessing the efficacy of a first year business course designed to develop skills for academic success, provide a sense of community, ease the transition to college, and provide a realistic preview of business school expectations.

\section{Appendix A}

Variables Used to Assess Student Outcomes

\begin{tabular}{|l|l|}
\hline Variable Name & Description \\
\hline Demographic Variables & age of student \\
\hline AGE & $=1$ if student is male \\
\hline MALE & $\begin{array}{l}=1 \text { if student self-reports as Black, Hispanic, or } \\
\text { Native American }\end{array}$ \\
\hline MINORITY & $=1$ if student lives off campus \\
\hline OFF & $=1$ if student has not declared a major \\
\hline UNDEC & \\
\hline & high school average \\
\hline Academic Variables & Oswego GPA up to Fall 2002 \\
\hline HSAV & highest combined SAT score \\
\hline OSGPA & \\
\hline SAT & \\
\hline Financial Variables & $=1$ if student is receiving grants \\
\hline GRANT & $=1$ if student is receiving loans \\
\hline LOAN & The dollar amount of unmet need for financial aid \\
\hline NEED & $=1$ is student is receiving work study \\
\hline WKST & \\
\hline & \\
\hline First Year Program Variable & $=1$ if student enrolled in MGT 110, Fall 2001 \\
\hline MGT110 & \\
\hline & \\
\hline Retention Variables & $=1$ if GPA < 1.76 \\
\hline DQ & $=1$ if student is registered for Fall 2002 \\
\hline RET & \\
\hline &
\end{tabular}




\section{Appendix B}

\section{Summary Statistics for the 2001 Freshman Class}

(Items in bold in the table are statistically different from those not in the specified group at the $5 \%$ level)

\begin{tabular}{|c|c|c|}
\hline \multicolumn{3}{|l|}{ Freshman Class Fall 2001} \\
\hline & $\begin{array}{l}\text { General } \\
\text { Admits } \\
\end{array}$ & $\begin{array}{l}\text { MGT } 110 \\
\text { Participants }\end{array}$ \\
\hline \# of students & 1136 & 179 \\
\hline \% of total freshman & $83 \%$ & $13 \%$ \\
\hline \% returning Fall 2002 & $78 \%$ & $82 \%$ \\
\hline \multicolumn{3}{|l|}{ Academic Data } \\
\hline SAT average & 1080 & 1023 \\
\hline \% not reporting SAT & $3 \%$ & $4 \%$ \\
\hline HS average & 87.16 & 85.34 \\
\hline GPA (up to Fall 2002) & 2.56 & 2.56 \\
\hline \multicolumn{3}{|l|}{ Demographic Data } \\
\hline$\%$ female & $54 \%$ & $47 \%$ \\
\hline$\%$ minority & $4 \%$ & $14 \%$ \\
\hline average age & 18.65 & 18.55 \\
\hline \% living off campus & $11 \%$ & \\
\hline \multicolumn{3}{|l|}{ Financial Data } \\
\hline average unmet need & $\$ 907.50$ & $\$ 1,244.86$ \\
\hline average Household income & $\$ 62,376.11$ & $\$ \$ 56,467.88$ \\
\hline
\end{tabular}




\section{Appendix C}

Single Equation Probit Estimation Results, Marginal Probabilities (P-values in parentheses)

\begin{tabular}{lll}
\hline & RET & DQ \\
\hline HSAV & $.01106^{* *}$ & $-.01750^{* *}$ \\
MALE & $(.000)$ & $(.000)$ \\
& -.00009 & $.03396^{*}$ \\
MINORITY & $(.997)$ & $(.076)$ \\
& $(.04061)$ & $.06103^{*}$ \\
AGE & .00312 & $(.094)$ \\
& $(.664)$ & -.00951 \\
OFF & $-.15570^{* *}$ & $(.165)$ \\
& $(.000)$ & $.13161^{* *}$ \\
UNDEC & -.00712 & $(.000)$ \\
& $(.789)$ & -.00475 \\
NEED & $-.00002^{* *}$ & $(.825)$ \\
& $(.000)$ & $.00001^{* *}$ \\
LOAN & $-.06814^{* *}$ & $(.000)$ \\
& $(.020)$ & .00620 \\
WKST & $.14318^{* *}$ & $(.803)$ \\
MGT 110 & $(.000)$ & $-.11853^{* *}$ \\
& $\left(.09455^{*}\right.$ & $(.000)$ \\
Pseudo R2 & .0748 & $-.04321^{*}$ \\
\hline \hline N & & $(.102)$ \\
$\chi^{2}(16)$ & 106.59 & 1335 \\
\hline
\end{tabular}

** significant at the $5 \%$ level

*significant at the $10 \%$ level 


\section{Appendix D}

Regression Coefficients (P-values in parentheses)

\begin{tabular}{|c|c|}
\hline & OSGPA \\
\hline HSAV & $\begin{array}{l}.03700^{* *} \\
(.007)\end{array}$ \\
\hline MALE & $\begin{array}{l}-.02254 \\
(.820)\end{array}$ \\
\hline MINORITY & $\begin{array}{l}.22867 \\
(.320)\end{array}$ \\
\hline AGE & $\begin{array}{l}.02799 \\
(.353)\end{array}$ \\
\hline OFF & $\begin{array}{l}-.37268^{* *} \\
(.000)\end{array}$ \\
\hline UNDEC & $\begin{array}{l}.05097 \\
(.718)\end{array}$ \\
\hline NEED & $\begin{array}{l}-.00002 \\
(.306)\end{array}$ \\
\hline LOAN & $\begin{array}{l}.09767 \\
(.412)\end{array}$ \\
\hline WKST & $\begin{array}{l}.27477^{*} \\
(.094)\end{array}$ \\
\hline GRANT & $\begin{array}{l}-.10961 \\
(.520)\end{array}$ \\
\hline MGT 110 & $\begin{array}{l}.13213^{* *} \\
(.031)\end{array}$ \\
\hline \multicolumn{2}{|c|}{$\begin{array}{l}{ }^{* *} \text { Significant at the } 5 \% \\
\text { level }\end{array}$} \\
\hline $\mathrm{N}$ & 1334 \\
\hline$F(17,1316)$ & $\begin{array}{l}24.85 \\
(.000)\end{array}$ \\
\hline Adjusted R2 & .2332 \\
\hline
\end{tabular}




\section{Appendix E}

An Example of the Estimated Impact of MGT 110 on Student Outcomes

\begin{tabular}{|l|c|c|}
\hline \multicolumn{2}{|c|}{$\begin{array}{c}\text { White Male, 19 years old } \\
\text { High School Average = 80\% } \\
\text { No financial aid, NEED }=0 \\
\text { Living off campus }\end{array}$} \\
No participation in any first-year programs \\
\hline \hline & $\begin{array}{c}\text { Without } \\
\text { MGT 110 }\end{array}$ & $\begin{array}{c}\text { If enrolled in } \\
\text { MGT 110 }\end{array}$ \\
\hline $\begin{array}{l}\text { Probability of returning in } \\
\text { the Fall 2002 }\end{array}$ & $60 \%$ & $67 \%$ \\
\hline $\begin{array}{l}\text { Probability of academic } \\
\text { disqualification }\end{array}$ & $49 \%$ & $41 \%$ \\
\hline Estimated first-year GPA & 2.19 & 2.32 \\
\hline
\end{tabular}




\section{Appendix F}

An Example of the Estimated Impact of MGT 110 on Student Outcomes

\begin{tabular}{|l|c|c||}
\hline \multicolumn{2}{|c|}{$\begin{array}{c}\text { Minority Female, 18.5 years old } \\
\text { High School Average = 87\% } \\
\text { Receiving student loans, NEED = \$1000 }\end{array}$} \\
\hline & $\begin{array}{c}\text { Without } \\
\text { MGT 110 }\end{array}$ & $\begin{array}{c}\text { If enrolled in } \\
\text { MGT 110 }\end{array}$ \\
\hline $\begin{array}{l}\text { Probability of returning in } \\
\text { the Fall 2002 }\end{array}$ & $78 \%$ & $84 \%$ \\
\hline $\begin{array}{l}\text { Probability of academic } \\
\text { disqualification }\end{array}$ & $11 \%$ & $7.5 \%$ \\
\hline \hline Estimated first-year GPA & 3.11 & 3.24 \\
\hline
\end{tabular}




\section{Appendix G \\ EBI First Year Initiative Student Assessment Items}

Mean Responses $(n=152)$

(1=not at all, $4=$ somewhat, $7=$ significantly)

\begin{tabular}{|l|l|}
\hline Item & Mean \\
\hline Taking this class improved my commitment to completing my degree & 5.29 \\
\hline $\begin{array}{l}\text { Taking this class increased the degree to which I completed homework } \\
\text { assignments on time }\end{array}$ & 5.68 \\
\hline $\begin{array}{l}\text { Taking this class improved the degree to which I set priorities so I can } \\
\text { accomplish what is most important to me }\end{array}$ & 5.23 \\
\hline $\begin{array}{l}\text { Taking this class improved my ability to meet new people } \\
\begin{array}{l}\text { To what degree did this course include encouragement for students to } \\
\text { work together }\end{array}\end{array}$ & 5.95 \\
\hline To what degree are you accepted by students at this college/university & 5.74 \\
\hline $\begin{array}{l}\text { To what degree is it easy for you to make new friends at this } \\
\text { college/university }\end{array}$ & 5.48 \\
\hline $\begin{array}{l}\text { For the next academic year to what degree do you plan to return to this } \\
\text { college/university }\end{array}$ & 5.77 \\
\hline $\begin{array}{l}\text { For the next academic year to what degree do you plan to transfer to } \\
\text { another college/university }\end{array}$ & 4.99 \\
\hline $\begin{array}{l}\text { For the next academic year to what degree do you plan to not enroll in } \\
\text { any college/university (Note: scale is reversed) }\end{array}$ & 6.4 \\
\hline \begin{tabular}{l} 
To what degree would you recommend this college/university to a friend \\
\hline
\end{tabular} & 5.49 \\
\hline
\end{tabular}




\section{Appendix $\mathrm{H}$ \\ Transition to College Item Responses}

Percentage responding $(n=157)$

( $a=$ strongly agree, $b=$ somewhat agree, $c=$ undecided or no opinion, $d=$ somewhat disagree, $e=$ strongly disagree)

\begin{tabular}{|c|c|c|c|c|c|}
\hline Survey statement & A & b & c & d & e \\
\hline $\begin{array}{l}\text { School of Business academic } \\
\text { expectations }\end{array}$ & $41 \%$ & $39 \%$ & $11 \%$ & $4 \%$ & $4 \%$ \\
\hline Introduction to helpful resources & $46 \%$ & $38 \%$ & $8 \%$ & $8 \%$ & $1 \%$ \\
\hline $\begin{array}{l}\text { Close bond with other business } \\
\text { students }\end{array}$ & $38 \%$ & $34 \%$ & $15 \%$ & $10 \%$ & $3 \%$ \\
\hline $\begin{array}{l}\text { Improvement in stress } \\
\text { management }\end{array}$ & $24 \%$ & $41 \%$ & $17 \%$ & $14 \%$ & $4 \%$ \\
\hline Improvement in time management & $24 \%$ & $39 \%$ & $18 \%$ & $11 \%$ & $5 \%$ \\
\hline Support in my transition to college & $41 \%$ & $39 \%$ & $11 \%$ & $4 \%$ & $4 \%$ \\
\hline
\end{tabular}




\section{References}

Accounting Education Change Commission. (August, 1990). AECC urges priority for teaching in higher education, Issue Statements No. 1 (Torrence, CA.).

ACT (2000).National college dropout and graduation rates, 1999. www.act.org/news/releases/200/02-16b00.html.

Allen, D. (1999). Desire to finish college: An empirical link between motivation and persistence. Research in Higher Education, 40(4), 461-485.

Astin, A.W. (1993). What matters in college? Four critical years revisited. San Francisco: Jossey-Bass.

Baker, S., \& Pomerantz, N. (2000). Impact of learning communities on retention at a metropolitan university. Journal of College Student Retention, 2(2), 115-126.

Barefoot, B. (1993). Exploring the evidence: Reporting outcomes of freshman seminars. The freshman year experience: Monograph series number 11. South Carolina. (ERIC Document Reproduction Service No. ED 367 214).

Barefoot, B. (1994). The freshman seminar: A flexible fixture in American higher education. Columbia, S.C.: National Resource Center for The Freshman Year Experience.

Bobrowski, P.E. \& Cox, P.L. (2004). Gateway to Business (4 ${ }^{\text {th }}$ Edition). Corvallis, Oregon: Pacific Crest.

Boyer, E. (1997). College: The undergraduate experience in America. New York: Harper \& Row.

Braxton, J., Milem, J. \& Sullivan, S. (2000). The influence of active learning on the college student departure process. The Journal of Higher Education, 71(5), 569-590.

Chanko, L.B. \& Roberts, J. A. (1996). An innovative introduction to business course: Marketing the skills that marketing majors and others as business majors will need for success. Marketing Education Review, Fall, 53-77.

Chickering, A.W. (1969). Education and identity. San Francisco: Jossey-Bass.

Congos, D. H., \& Schoeps, N. (1999). Methods to determine the impact of SI programs on colleges and universities, Journal of College Student Retention, 1(1), 59-82. 
Consortium for Student Retention Data Exchange. (1999). Executive summary 19881999 CSRDE report: The retention and graduation rates in 269 colleges and universities. Norman, OK: Center for Institutional Data Exchange and Analysis, University of Oklahoma.

Cox, P.L. \& Bobrowski, P.E. (2000). The team charter assignment: Improving the effectiveness of classroom teams. Journal of Behavioral and Applied Management, 1 (2), 92-103.

Cuseo, J.B. (1991). The freshman orientation seminar: A research-based rationale for its value, deliver, and content. (Monograph \#4). Columbia, SC: University of South Carolina, National Resource Center for the Freshman Year Experience.

Davis, B. (1992). Freshman seminar: A broad spectrum of effectiveness. Journal of the Freshman Year Experience, 4, 79-94.

DeBerard, M.S., Spielmans, G.I., \& Julka, D.L. (2004). Predictors of academic achievement and retention among college freshman: A longitudinal study. College Student Journal, 38(1), 66-80.

Federman Stein, D.R. (1997). Conditions that facilitate the implementation of innovative freshman experience courses: A comparative analysis of three courses, Ph.D. dissertation, Syracuse University.

Fidler, P.P. (1991). Relationship of freshman orientation seminars to sophomore return rates. Journal of the Freshman Year Experience, 3, 7-38.

Frost, S. (1993, Summer). Strategies to help freshmen succeed. Planning for higher education, 21.

Gordon, V.N., \& Gites, T.J. (1984). The freshman seminar course: Helping students succeed. Journal of College Student Personnel, 25, 315-320.

Greene, W.H. (1990). Econometric Analysis. New York: Macmillan Publishing Co.

Hoyt, J.E. \& Winn, B.A. (2004). Understanding retention and college student bodies: Difference between drop-outs, stop-outs, opt-outs, and transfer-outs. NASPA Journal (Online), 41(3), 395-417.

Hyers, A.D., \& Joslin, M.N. (1996). The first year seminar as a predictor of academic achievement and persistence at a small state liberal arts college in the U.S. Unpublished manuscript (Version D8). North Adams, MA: North Adams State College. 
Johnson, J. (1997). Commuter college students: What factors determine who will persist and who will drop out? College Student Journal, 31(3), 323-333.

Johnson, D.W., Johnson, R.T., \& Smith, K.A. (1991). Active Learning: Cooperation in the college classroom. Edina, MN: Interaction Book Company.

Kluepfel, G.A. \& Roberts, G. (1994). Introduction: Special issue on retention programs. Journal of Developmental Education, 17, 2-3.

Kuh, G., Schuh, J., \& Whitt, E. (Eds). (1991). Involving colleges: Successful approaches to fostering student learning and development outside the classroom. San Francisco: Jossey-Bass.

Lamb, C.H., Lee, J.B., \& Vinton, K.L. (1997). Developing a freshman seminar: Challenges and opportunities. Journal of Management Education, 21, 1, 27-43.

Lau, L.K. (2003). Institutional factors affecting student retention. Education, 124(1), 126136.

Lent, R.W., Brown, S.D., \& Lark, K.C. (1991). Relation of self-efficacy expectations to academic achievement and persistence. Journal of Counseling Psychology, 31, 356362.

Levitz, R.S., Noel, L., \& Richter, B.J. (1999). Strategic moves for retention success. In G.H. Gaither (Ed.), Promising practices in recruitment, remediation, and retention (pp. 31-50.) New Directions for Higher Education, n. 108. San Francisco: Jossey-Bass.

Logan, C.R., Salibury-Glennon, J., \& Spence, L.D. (2000). The learning edge academic program: Toward a community of learners. Journal of the Freshman Year Experience, 12, 77-104.

Mason, J.C. (1992). Business schools: Striving to meet customer demand. Management Review, September, 21-27.

Milem, J., Berger, J. (1996). A modified model of college student persistence: Exploring the relationship between Astin's Theory of Involvement and Tinto's Theory of Student Departure. Paper presented at the annual meeting of the Association for the Study of Higher Education.

Miller, J.A. (1991). Experiencing management: A comprehensive, "hands-on" model for the introductory undergraduate management course. Journal of Management Education, 15, 2, 151-169. 
Mitchell, D.F., Goldman, B.A., \& Smith, M. (1999). Change factors affecting college matriculation: A re-analysis. Journal of the First-Year Experience and Students in Transition, 41(3), 395-417.

Murtaugh, P., Burns, L., Schuster, J. (1999). Predicting the retention of university students. Research in Higher Education, Vol. 40, 3, 355-31.

Napoli, A. \& Wortman, P. (1998). Psychosocial factors related to retention and early departure of two-year community college students. Research in Higher Education, 39, 355-371.

National Resource Center for The First-Year Experience and Students in Transition. (2000). 2000 national survey of first-year seminar programming. Available:

http://www.sc.edu/fye/research/surveys/survey00.htm.

Noel, L., Levitz, R., \& Saluri, D. (Eds.) (1985). Increasing student retention. San Francisco: Jossey-Bass.

Pascarella, E.T. \& Terenzini, P.T. (1991). How college affects students. San Francisco: Jossey-Bass.

Porter, L.W. \& McKibbin, L.E. (1988). Management education and development: Drift or thrust into the $21^{\text {st }}$ Century. New York: McGraw-Hill.

Reason, R.D. (2003). Student variables that predict retention: Recent research and new developments. NASPA Journal (Online), 40(4), 172-191.

Richardson, S.M. (1994). Identifying non-cognitive factors that influence success of academically under-prepared freshman. Journal of the Freshman Year Experience, 6 (2), 89-100.

Robert, E., \& Thomson, G. (1994). Learning assistance and the success of underrepresented students at Berkely. Journal of Developmental Education, 7(3), 1-14.

Rodger, S. \& Tremblay, P.F. (2003). The effects of a peer mentoring program on academic success among first-year university students. The Canadian Journal of Higher Education, 33(3), 1-18.

Ryan, M.P. \& Glenn, P.A. (2004). What do first-year students need most: Learning strategies or academic socialization? Journal of College Reading and Learning, 34(2), 4-28.

Sanders, L. \& Burton, J.D. (1996). From retention to satisfaction: New outcomes for assessing the freshman experience. Research in Higher Education, 37, 555-567. 
Schutt, N.S. \& Malouff, J.M. (2002). Incorporating emotional skills content in a college transition course enhances student retention. Journal of The First-Year Experience, 14, $1,7-21$.

Seidman, A. (1991). Faculty can make a difference in student persistence. Colleague. State University of New York, 21-25.

Sidle, M.W. \& McReynolds, J. (1999). The freshman year experience: Student retention and student success. N ASPA Journal, 36(4), 288-300.

Skipper, T.L. (2002). Survey results and analyses. In National Resource Center for the First-Year Experience and Students in Transition, The 2000 national survey of first-year programs: Continuing innovations in the collegiate curriculum. (The First-Year Monograph Series No. 33, pp. 11-76). Columbia, SC: University of South Carolina. ERIC Document Reproduction Service No. ED471258.

Soldner, L., Lee, Y.,\& Duby, P. (1999). Welcome to the block: Developing freshman learning communities that work. Journal of college student retention, 1, 2, 115-29.

Starke, M.C., Harth, M., \& Sirianni, F. (2001). Retention, bonding, and academic achievement: Success of a first-year seminar. Journal of the First-Year Experience and Students in Transition, 13, 2, 7-35.

Strumpf, G. \& Hunt, P. (1993). The effects of an orientation course on the retention and academic standing of entering freshmen: Controlling for the volunteer effect. Journal of the Freshman Year Experience, 5(1), 7-14.

The Boyer Commission Report on Educating Undergraduates in the Research University. (1995). Reinventing undergraduate education: A blueprint for America's research universities. New Jersey: Carnegie Foundation.

Thomas, R.O. (1990). Programs and activities for improved retention. In D. Hossler, J.P. Bean \& Associates (Eds.), The strategic management of college enrollments (pp. 186201). San Francisco: Jossey-Bass.

Thomas, S. (2000). Ties that bind. The Journal of Higher Education, 71 (5), 591-615.

Tinto, V. (1990). Principles of effective retention. Journal of the Freshmen Year Experience, 2 (1), 35-48.

Tinto, V. (1993, 1987). Leaving college: Rethinking the causes and cures of student attrition. Chicago: University of Chicago Press.

Tinto, V. (1996). Reconstructing the first year of college. Planning for Higher Education, 25, 1-6. 
Tinto, V. (1999). Taking retention seriously: Rethinking the first year of college. NACADA Journal, 19, 2, 5-9.

Tinto, V. (2002). Promoting student retention: Lessons learned for the United States. Presentation at the $11^{\text {th }}$ Annual Conference of the European Access Network, Prato, Italy, June 19, 2002.

Wagner, U., \& Nettles, M. (1998). It takes a community to educate students: How three HBCUs succeed at retention. Change: The Magazine of Higher Learning, 20 (2), 18-25. 